HOW

Volume 28, Number 3, pages $62-77$

https://doi.org/10.19183/how.28.3.682

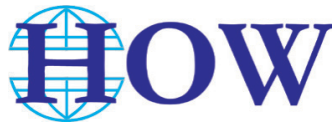

\title{
Criticality and English Language Education: An Autoethnographic Journey
}

Criticidad y educación en inglés:

Un trayecto autoetnográfico

\section{Raúl Alberto Mora ${ }^{1}$}

\begin{abstract}
This article, relying on a series of epiphanies throughout my journey as a researcher and scholaractivist, shares my relationship with criticality and how it has guided my research and teaching agendas. I share how critical theories have informed my main research areas and the questions and issues I have raised in my own work. The article also discusses my main scholarly influences and how my interactions with varied literature, mentors, and colleagues have shaped my own criticality. I also take a moment to reflect on how this journey has helped the field of language education in Colombia to continue with the evolution toward stronger critical and social justice-oriented frameworks and how I see my changing positionality as mentor and ally of colleagues and the future cadres of scholars moving forward.
\end{abstract}

Keywords: criticality, autoethnography, English language education, advocacy

\section{Resumen}

Este artículo, que usa una serie de revelaciones a lo largo de mi trayecto como investigador y académico-activista, comparte mi relación con la criticidad y cómo esta ha guiado mis agendas de investigación y docencia. Comparto cómo las teorías críticas han ilustrado mis temas de investigación principales y las preguntas y asuntos que he generado en mi propio trabajo. El artículo también discute mis principales influencias académicas y cómo mis interacciones con la literatura, mentores y colegas

He is Associate Professor at Universidad Pontificia Bolivariana. He also chairs the Literacies in Second Languages Project research lab at UPB. Raúl Mora's research explores literacies theory from a socio-critical perspective to transform second language education practices and studies L2 literacy practices in urban and virtual spaces.

raul.mora@upb.edu.co

ORCID ID: https://orcid.org/0000-0003-0479-252X

Received: August 29th, 2021. Accepted: September 8th, 2021.

This article is licensed under a Creative Commons Attribution-Non-Commercial-No-Derivatives 4.0 International License. License Deed can be consulted at https://creativecommons.org/licenses/by-nc-nd/4.0. 
han forjado mi criticidad. También aprovecho el momento para reflexionar sobre cómo este trayecto ha aportado a que el campo de la educación en lenguas en Colombia continúe su evolución hacia marcos críticos y de justicia social más fuertes y cómo veo mi cambiante posicionalidad como mentor y aliado de otros colegas y las futuras generaciones de académicos de aquí en adelante.

Palabras clave: criticidad, autoetnografía, educación en inglés, abogacía

\section{Introduction: How I (Of All People) Got Here}

First Epiphany: Fall 2005, University of Illinois

At the request of my adviser at the time (Dr. Renée T. Clift), I asked for an appointment with Dr. Antonia Darder (a Puerto-Rican critical theorist and activist) to ask questions about critical theory. Dr. Darder asked me one question (because it seems all academic journeys always begin with one pivotal question): Why do you want to study critical theory?

That question (and Antonia's answer, as I shared with her in a serendipitous moment at O'Hare International Airport in 2015) made me think about the why of everything I do to this day.

English language teaching and education have always had a really weird relationship with criticality, sometimes resembling (making a quick reference to current TV show Ted Lasso) romantic comedies. It has been one of love and hate, as well as acceptance and denial. As researchers in a field, we are still coming to terms with what it means to be critical in a field like ELT (Banegas \& Villacañas de Castro, 2016) while facing the good, the bad, and the ugly inherent to teaching a language such as English (Guerrero, 2009; González, 2011; Kubota, 2021). ETL scholars and practitioners have gravitated towards ideas such as critical thinking and critical reading over the years. Most recently, critical literacy (Mora, 2014c) has become a topic of extended interest in our field (see Mora, Cañas, Gutiérrez-Arismendy, Ramírez, Gaviria, \& Golovátina-Mora, 2021, for an extended review). This interest has particularly emerged in teacher education (see Ramírez, 2020, 2021, for a meta-analysis of the field) as pre-service and in-service teachers are raising new questions about what we do and how to infuse our work within stronger views of social justice (Ortega, 2019; Sierra Piedrahita, 2016) and equitable frameworks in our policies and instructional practices (Mora, Chiquito, \& Zapata, 2019).

When HOW journal invited me of all people (and when I say "of all people," it is because it has been difficult yet so interesting to come to terms with the idea of assessing the impact of my work) to share my insights about my own work and how it overlaps with the growth of the field of ELT in Colombia, I had to ponder how to approach it. I chose to talk about criticality as my relationship with critical theories has highly informed and influenced my academic evolution, especially in the past two decades (when I have moved from being a school teacher to being a graduate student and now a teacher educator, researcher, and advocate/co-conspirator to other teachers in Colombia). 
This article will keep in mind the spirit and format for this special issue, imbuing my thoughts about the field and my conceptual reflexivity (Bourdieu \& Wacquant, 1992; Mora, 2012, 2014x) with some autoethnographic epiphanies (Denzin, 2013) to reflect on the journey (Bresler, 2021; Forber-Pratt, 2015). In that sense, this article affords me both a moment of gratitude about the road traveled and a challenge to think of the road ahead so that our ELT community, as a community of learning and activism, can be more critical and better at criticality, especially as the field of language education in Colombia keeps asking harder and deeper questions about what and why we learn and teach languages (Mora, 2013a) and what that means for the changing sociopolitical landscape of our home country.

\section{Criticality and ELT: My Roots and Routes}

Second Epiphany: 1999, Medellín

I had my first publication ever (Mora, 1999) in HOW journal. I wrote an article about how I used project work to help my students improve their writing skills. Although the paper did not have a critical framework around it, I reflected later as a grad student on how there were elements of action research in its conception. As I looked back at my maiden voyage as an academic writer (one that I have learned to be kinder to as I have grown as a writer and scholar over the years), I can see in that paper that Raúl, a school teacher in Medellin, wrote the foundations of quite a few of the questions that Raull, the graduate student in the United States, and Raúl, the college professor in Medellin, have brought up in my scholarship, research, and advocacy.

My formal introduction to critical theory came in graduate school, as I took courses on Critical Literacy, Action Research, Critical Race Theory, and Critical Discourse Analysis, and it continues today as I teach a doctoral-level seminar on Introduction to Critical Theory. However, my introduction to criticality started much earlier. I may even trace it back to my undergraduate years (1992-1994), when I started attending local ELT conferences and the ASOCOPI congress. There is one word in Russian (a language I am close to by marital proxy [Mora \& Golovátina-Mora, 2017b]) that I am very fond of: pochemucbka (nочемyчкa), an untranslatable word, usually described as "a person who asks too many questions." However, the thing I like about pochemuchka is that it does not have a negative connotation. Rather, asking too many questions in this sense is something worth nurturing, as too many questions

64 are a sign of curiosity. Those who have followed my academic career do know this to be a fact: There is no conference I have ever attended, no class I have ever taken, where I do not feel compelled to raise my hand to ask a question. I have been a pochemuchka my entire academic career and I doubt I will be slowing down as I get older.

I bring up this reference to pochemuchka because raising questions is at the core of a critical mindset. Raising questions about what I have seen as a teacher has laid the foundation to my background as a critical scholar and co-conspirator (Love, 2019). Criticality has been 
my conceptual North Star (Love, 2019) for three focal points that inform my scholarship, teaching, and research. I will unfold these points in this section.

\section{Critical Literacy}

My initial framing as a literacy scholar was as someone who worked on "alternative literacy paradigms" (Mora, 2011), which comes directly from my own work in critical literacy (Mora, 2014c; Mora et al., 2021). Critical literacy always invites teachers and teacher educators to ask bigger questions about language in society and how to foster the use of, in our case, English and other second languages (Mora, 2013b) as tools for equity and social agency. In this vein, when I advocate for critical literacy in our field (Mora, 2014c), I am also advocating for the disruption of segmented views of criticality, sometimes espoused in certain views of what we refer to as "critical thinking" or even "critical reading." These views, I would argue, often lack the epistemological foundations that critical literacy possesses, where talking about or, in our case, teaching a language means keeping in mind the sociopolitical or economic implications of this term (Luke, 2017). Critical literacy here means thinking about better ways to learn, teach, and use English, better ways to make the language real and relevant (as opposed to just making it, say, "authentic"), and confronting neoliberal models that continue to permeate the discourse about language teaching and, yes, even the misuse of the term "critical" (Mora, Pandya, Alford, Golden, \& de Roock, 2021).

\section{Acronyms, Frameworks, and Terms We Hold Near and Dear}

Critical theory and criticality have also guided a series of questions I have raised in the past decade about the terms we use (and sometimes hold deep emotional attachments to) in ELT. I believe that constantly questioning what we mean by these terms and how they come into play in everyday classrooms is necessary to avoid turning these terms into commonplace ones. Raising questions about notions such as bilingualism (Mora, 2014d; Mora \& Golovátina-Mora, 2011; Mora et al., 2019) or the EFL/ESL binary (Mora, 2011, 2012, 2013, 2017b, 2019; Mora \& Golovátina-Mora, 2017a) is urgent and necessary. I have been particularly adamant about the need to problematize (Mora, 2012) and transcend (Mora, 2017b, 2019) the traditional framing of English as either a second or foreign language. I particularly believe we need to think of more inclusive frameworks devoid of the strong social inequities already present (and increasingly louder) in a notion such as EFL and the risks of how it can marginalize students in public urban and rural schools, especially when elite private schools keep pushing ESL curricula under the guise of being "bilingual schools" or promoting "bilingual education." 


\section{Global South Advocacy ${ }^{2}$}

My views on criticality have also surfaced in how I frame my scholarly positionality as a scholar from and in the Global South (Mora, Cañas, Rosas Chávez, Rocha, \& Maciel, 2020). I have advocated in my own work and publications (and even in my recent efforts in international associations, including my incoming three-year appointment to the Literacy Research Association Board of Directors starting December 2021) for a view of the Global South as knowledge creators and not just as vessels receiving knowledge from the Global North (Mora et al, 2021a), but always advocating for dialogic and not reactionary views of the relationship between North and South where we invite the North, recalling some of Vanilla Ice's lyrics, to "stop, collaborate, and listen" as we create fruitful global relationships and think of better ways for us in the South to engage in refined forms of glocal advocacy (Mora, 2016a) that also include the multiple languages and Englishes at play in our regions (Mora, 2016b).

\section{Criticality and ELT: The Influences}

Third Epiphany: Fall 2004, University of Illinois

My first course as a doctoral student was Critical Literacy with Professor Arlette Willis. I found it so interesting how we started from critical theory and only talked about critical literacy mid-semester. That progression, and Prof. Willis' gift to me of a copy of Freire's Pedagogy of the Oppressed, were two big takeaways from that class. Interestingly enough, I found that similar return-to-Frankfurt-School approach in other classes I took. like Action Research and Critical Race Theory and that was the basis to propose the doctoral seminar on Intro to Critical Theory I teach at Universidad Pontificia Bolivariana UPB.

Fourth Epiphany: December 2018, Indian Wells, CA

I have an ongoing tradition at the Literacy Research Association annual meeting where I meet for coffee with my mentor, Prof. Willis, before the conference begins. We talke about life, our families, and eventually we talk about literacy as peers and friends (although, truth be told, I always leave learning something else from Arlette). In that moment, we talked about the perils of losing track of the historical roots of concepts. I always recall that conversation when I talk to my students about critical theory, critical literacy, research, and even language teaching methods in my undergraduate course.

My journey as a critical scholar (a framing I do not take lightly, for I am fully aware of the responsibilities, implications, and risks of wearing such a mantle) has mixed multiple views

In this section I will discuss three terms: Global North, Global South, and glocal. Global North is a socio-political construct that describes countries and regions (many English dominant) that have usually led academic and curricular decisions. Global South refers to emerging regions moving past the dominant discourses to propose new frameworks to participate in the academic and curricular debates. The idea of glocal refers to a mindset that addresses global problems from local perspectives. 
stemming from ideas, readings, and conversations across and between the Global South and North, sprinkled with references to popular culture (which, if one stops to listen, can offer valuable lessons worth bringing to one's classes). Conceptually, my views of criticality mix scholars from different eras and diverse readings that I have encountered in my career, especially since graduate school. Looking at critical theory itself, three authors have informed my views of criticality over the years. The first influence, hearkening back to the Frankfurt School, is Theodore W. Adorno. I remember well my first encounter with Adorno in that Critical Literacy course I took at Illinois. I found it salient in Adorno's work how he raised questions about popular culture (Brown, 1992; Witkin, 2003). Although some of his views are debatable, Adorno's initial questions laid the foundation to keep asking questions about popular culture and its value in our classrooms (e.g., Mora, 2006, 2017a).

The second influence, much deeper in my budding scholarship as a graduate student, is the work of Pierre Bourdieu. I have studied Bourdieu's work and discussed his influence and legacy (Mora, 2012) and even attempted to analyze his framework through movies (Mora \& Golovátina-Mora, 2014). Bourdieu's influence in my critical positionality mostly stems from the need to look carefully at language as a site of social reproduction and power (Bourdieu, 1991; Bourdieu \& Passeron, 1990) and the need to always imbue our educational reflections within science and research, of what Bourdieu describes in his idea of reflexivity (Bourdieu \& Wacquant, 1992; Mora, 2012, 2014e). Reflexivity is one of the cornerstones of my entire teaching ethos. I make that explicit in every syllabus I write and in my own lessons. Everything I do as a teacher and mentor is deeply framed as a space of reflexivity.

Finally, as a literacy scholar in particular, I cannot deny the influence of the work of Paulo Freire. That, as we celebrate his centennial, might sound like shameless product placement or just opportunism, but I have read and studied Freire for over 15 years, thus bringing that up is rather opportune. Freire's ideas about "reading the word and the world" (Freire \& Macedo, 1987), which are baseline elements for a critical view of literacy today, first inspired me to do research about the cities as literacy sites (Mora, 2015; Mora, Pulgarín, Ramírez, \& Mejía-Vélez, 2018). More recently, Freire's work on conscientização (Freire, 1979; Mora 2014a) was the cornerstone of a recent work with my researchers at the Literacies in Second Languages Project (LSLP) (Mora, 2015) merging multimodal design and conscientização to give a stronger critical dimension to meaning-making processes in our language classes (Mora, Tobón-Gallego, Mejía-Vélez, \& Agudelo, 2022).

Nevertheless, my journey through criticality does not end with Adorno, Bourdieu, and Freire. That is where it began. Over the years, more ideas and scholars have joined that path I am treading. Ideas from Gramscian theory, especially hegemony (Jones, 2007), the notion of counter-storytelling from LatCrit (Mora, 2014b; Solórzano \& Yosso, 2001), ideas from Critical Race Theory (Ladson-Billings, 1998; Parker, 1998; Willis, 2008), and even elements from Feminist theory (Beiras, Cantera Espinosa, \& Casasanta Garcia, 2017; hooks, 2000; 
Walters, 2005) keep informing my ever-evolving (I'm not Pikachu, you know! - My students will understand this Easter Egg!) views around criticality and what it means, recalling LadsonBillings (1998), for a nice field like ELT.

Of course, one cannot build criticality just from reading. Criticality is about talking the talk, walking the walk... and talking the walk. I cannot deny the value of multiple conversations with both young and veteran scholars over the years. Conversations with young critical literacy scholars such as Claudia Cañas and Mónica López-Ladino (Cañas, Ocampo, Rodríguez, López-Ladino, \& Mora, 2008), Tatiana Chiquito (Chiquito, Restrepo, \& Mora, 2019; Mora, Chiquito, \& Zapata, 2019), --eliana d. and Diego Zapata-Pescador (d. \& ZapataPescador, 2021), or Edison Castrillón-Ángel (Castrillón-Ángel \& Mora, 2021), just to name a few of the talented mentees I have at LSLP, have given me perspective. I also think about the conversations about criticality I have had with international scholars such as Antonia Darder, Laurence Parker, the late Susan Noffke, Yolanda Sealey-Ruiz, Gholdy Muhammad, Marcelle Haddix, Jessica Zacher Pandya, Jennifer Alford, Noah Asher Golden, and Roberto de Roock (among many others) as instrumental in this evolution. And of course, my growing relationship with one of my greatest mentors, Arlette Willis, and how her scholarship has shaped my own through her writing (Willis, 2009, 2015, 2020) and all those Starbucks coffees we have had since I graduated in 2010.

\title{
Criticality in ELT: What Does It Mean to Be a Critical ELT Scholar and Advocate?
}

Fifth Epiphany: July 2006

\begin{abstract}
Accepting an invitation of then-ASOCOPI President, Dr. Rigoberto Castillo, I offered the Seminar on Research and ELT, hosted by Universidad Nacional. I recall there were teachers and teacher educators from all over the country (highlighted by the presence of Prof. Melba Libia Cárdenas as attendant; high praise to have her as part of the seminar, make no mistake!). I recall that seminar so fondly, as it was a beautiful opportunity to share what I was learning as a doctoral student with my Colombian colleagues (but bittersweet to an end because I was in Bogotá when my nieces, Isabella and Manuela, were born). One of the session's topics was 'What do we mean by 'Critical' when we say 'Critical'?" (Disclaimer: That is the title I recall as I wrote this vignette. I was unable to find the slides I used at the seminar!) and the entire session delved into the meanings and implications of framing oneself and one's work as "critical". As I look back on that seminar, I see the seeds I planted in that session in the courses I started teaching when I returned to Colombia, including my methods courses, my research courses, the master's literacy graduate seminar, and the Intro to Critical Theory doctoral seminar we offer at Universidad Pontificia Bolivariana (UPB).
\end{abstract}

A critical perspective around language education is more crucial than ever (Mora et al., 2021b). As I write this paper, I cannot ignore the glaring social inequities in the Colombian education system, exacerbated by the rampant corruption in the government. These 
situations continue to disenfranchise our students in urban and rural areas, furthering the education debt (Ladson-Billings, 2006) that keeps denying our students and teachers in these schools the resources that match their desire and ingenuity. I cannot ignore the fact that the push for tests and achievement scores keeps undermining the real-life and meaningful learning our students should enjoy in their schools and classrooms. However, as I point out the issues, I also return to the tenets of criticality, this time going back to Freire (2000) and how criticality and a critical praxis do not come from despair. Criticality stems from love and hope. Criticality stems from the search for better possibilities and from the idea, as my brother Noah Asher Golden always reminds me (while sharing "the gift of pie"), that we are here to fight... and win the good fight.

I am blessed with being in the field long enough (almost 30 years if I count my first days as a preservice teacher!) to grow with it. I have seen the progression in topics (highlighted in the articles and ideas from the brilliant scholars that wrote the other articles in this special issue) whenever I go to our local events and the ASOCOPI Annual Congress. I see in the risks that our master's and doctoral students are taking with their groundbreaking thesis and dissertation proposals, increasingly infused in critical, social justice, and decolonial frameworks. I see it in the publications in our Colombian journals and in the efforts of teacher educators and our school teachers to welcome a critical spirit to the very activities they propose in their classrooms.

Going back to my own efforts, and returning to the three topics I mentioned at the beginning of the article, I find it fitting to offer some suggestions for ELT and language teacher education.

\section{We Are Not Critically Literate; We Are Critical Literacy}

Writing this title, I recalled a 2009 counterpoint to an article by José Aldemar Álvarez about literacy (Mora, 2009). The counterpoint, titled "It's Not How Literate We Are, It's How We Are Literate", brings to mind the idea I want to share in this section. As Mora and colleagues (2021b) pointed out in the conclusion to The Handbook of Critical Literacies, "Critical literacy is not just a buzzword or something we do. Critical literacy shapes who we are as teachers, as researchers, as scholars, as community members, and as family members." (Mora et al., 2021b, p. 465). Critical literacy is more than instructional practices, it is embodied actions and life lessons that become lesson plans and activities. It is life turned into questions that our students can embark upon by using the languages they are learning as their conduit.

We cannot think of critical literacy (or criticality for that matter) as instrumentality. It is life epistemology (Mora, 2016b); it is an ethos that begets techniques. If English language education wants to continue that progression toward real criticality, this is the first step we all must take: We need to understand that criticality as an everyday thing, rather than an add-on 
that we sprinkle on our lessons. Criticality means understanding that discussions of social justice, the inequities in our schools, the realities our students and teachers face, and the social, cultural, sexual, religious, or linguistic diversity that turns our classrooms into a true kaleidoscope, is something that we must talk about in language learning classes, in methods and approaches or didactics courses, in courses about ICT in ELT, in courses about grammar and pronunciation. Without that embodied criticality, without that sense that we do not do critical but we are critical, anything we do in our teacher education and professional development programs is going to ring hollow.

\section{We Can, Should, and Are Going to Do Better than ESL/EFL}

The questions about the ESL/EFL binary are questions ingrained in the perils of binary oppositions and the risks for teachers and teacher educators. Sustaining the use of those dichotomized concepts remains a tool for marginalization of our students and teachers alike. Notions like ESL and EFL might have served a purpose in previous decades, as they fit the zeitgeist of the days of the communicative approach and the other methods that preservice teachers may sometimes review in methods and approaches classes. But, in a world increasingly superdiverse (Blommaert \& Rampton, 2012; Giraldo \& Castaño, 2014) and globalized (Blommaert, 2010), such binary views of language use fail to address the realities of what our students and teachers do with language inside and outside of the schooling structures. My constant advocacy for this shift is the call for a better framework, one that recognizes the linguistic realities of Colombia and the multiplicity of Englishes already present in our cities across urban and rural areas (e.g., Cruz Arcila, 2018). We owe it to ourselves as a community of learning and advocacy to think of something better than we already have.

English in Colombia and what we as a community mean by it continues to evolve. But, remaining shackled to that EFL/ESL binary, with all its colonial (Brittain, 20201; Guerrero Nieto \& Quintero Polo, 2009) and raciolinguistic (Rosa \& Flores, 2017) undertones, cannot do the trick. EFL cannot help our students find their potential as language users in this new world. EFL is what keeps holding them back. Recalling a phrase I heard from my mentor, Arlette Willis, at a recent webinar, "The people who brought us to this place cannot be

70 the people who move us from this place!" 'This does not apply to just people. It applies to frameworks and acronyms too.

\section{We Are the Global South and We Have A Voice}

This year, Claudia Cañas, Gloria Gutiérrez-Arismendy, Natalia Andrea Ramírez, Carlos Andrés Gaviria, and Polina Golovátina-Mora, and I wrote a review about critical literacies in Colombia (Mora et al., 2021a). It was with great delight that we enjoyed reading and reviewing 
the work of all the scholars in higher education and schools who are doing and writing about critical literacy. As an ELT community from and in Colombia, from and in this region that we call the Global South, we are living an interesting moment: Our scholarship is truly coming of age. Colombia is a knowledge center and the world is listening. Great scholars paved the way for the work we are doing now, and looking at the cadres of master's and doctoral students in our local universities, I would say the future seems brighter than ever.

We need to think globally, not from reactionary views to the conversation with other regions, but in constructive ways where we lead the dialogue and keep learning from others who have traditions. We need to think grassroots, as our work in higher education must continue to create synergies with local schools and our neighborhoods. Criticality is about that dialogue, and that grassroots mentality to create communities (Rincón \& Clavijo-Olarte, 2016; Trigos-Carrillo, 2019). It is about having the strength to make our voices heard as scholars when our communities need us most while staying humble to listen to the knowledgeable voices in our communities and other places in the world. The ELT community in Colombia needs to be an advocate and co-conspirator of our teachers and teacher educators and help amplify those voices in the very places that are already poised to listen to us.

\section{Criticality and ELT: Me, an Influencer? A Role Model? When Did THAT Happen?}

Sixth Epiphany: October 2019 - ASOCOPI Annual Congress in Bogotá

I have always loved going to ASOCOPI since I first attended back in 1994 in Medellin. The presentations, the people there, the atmosphere has always given me inspiration to go back to my classroom and continue teacbing. The 2019 Congress felt so different. I have always had folx attending my sessions, some full, some emptier, but I have always felt I have something to say. But, this time in Bogotá, there was a different vibe. It wasn't just the colleagues listening to my presentations. It was the younger teachers and graduate students taking notes to my every suggestion. All of a sudden, I felt like I was in the place of those who built our field when I was a young teacher. It took me a while (and conversations with friends like Claudia Uribe, José Aldemar Alvarez. or Liliana Cuesta) to come to terms with the shifting roles and the responsibility that "my students" weren't just those at UPB anymore. "My students" in a way were all the students across our institutions who listened to my suggestions or reacbed out with a question or read my articles with such interest.

I sometimes use an expression with friends and in my Instagram feed, \#iamjustadude. I use it sometimes as a way to ground, sometimes undermine, my seeming influence in the fields of ELT and literacy studies in Colombia. And I still blush when I read a sentence like this, "Clavijo (2000) as well as Mora (2011) have led the study of literacies, generating indepth reflection on literacy practices in Colombia" (Castro Garcés, 2021, p. 178). When I read Ángela's article, I read this sentence at least three times, thinking, "SERIOUSLY? ME?" 
And no, this is not faux humility; think more in terms of the imposter syndrome we all deal with kicking in.

With this introduction, I think rather than describe how my work has arguably impacted the field of ELT in Colombia (I know it has. Just looking at my researchers at the Literacies in Second Languages Project, my \#LSLPLegion, is living proof); so, I think I want to use the final words in this article to thank those who have used my ideas about criticality expressed in my articles, presentations, and plenaries to build their own work.

I am aware that my work on critical literacy has informed recent research in the field and has given younger scholars in critical literacy more ideas to build their projects. I know that my questions about the ESL/EFL binary, even if still under scrutiny, have helped junior scholars think about their classrooms and what it means to teach English in Colombia. I know that Colombian professors elsewhere have used my articles to build their syllabi when they need to frame a literacy course and I am grateful my articles served that purpose. I am always humbled to hear from teachers about the ideas they drew from my presentations at the ASOCOPI annual conference or in my visits to colleagues at other universities here. If I still smile with glee when I see the citation alerts and see it was from an article by a Colombian scholar, it is because I know there has been an entire village that got me here and a \#worldwideacademicfam that nourishes me and sustains me. Because, at the end of the day, that is what embodying criticality looks like. It is about the gratitude for the roots that got you here, all the possible routes you keep taking, and the kindred spirits that you meet along the way. Criticality, being critical, living critical, is about raising your voice loudly to ask the hard questions and working even harder with others to come up with the needed answers.

My final words of gratitude go first to the HOW Editorial Committee for their persistence in getting me to write this article. I am honored and humbled by the text that transpired here. I want to thank all those who have shared writing with me, from my first co-author, Maria Catalina Lopera (Mora \& Lopera Gómez, 2001) to my current colleagues and mentees who still write with me, for the opportunities to write and learn together. Finally, all my love and gratitude to the four anchors that keep me grounded and safe in these uncharted waters of academia: my family, Polina, the Clan MacLeod, and my Legion at LSLP. It is thanks to them that I am a critical scholar. It is because of them that I cannot cease fighting to make criticality an everyday affair in our schools and scholarly lives.

\section{References}

Banegas, D. L., \& Villacañas de Castro, L. S. (2016). Criticality. ELT Journal, 70(4), 455-457. https://doi.org/10.1093/elt/ccw048 
Beiras, A., Cantera Espinosa, L. M., \& Casasanta Garcia, A. L. (2017). La construcción de una metodología feminista cualitativa de enfoque narrativo-crítico. Psicoperspectivas, 16(2), 54 65. https://doi.org/10.5027/psicoperspectivas-vol16-issue2-fulltext-1012

Blommaert, J. (2010). The sociolinguistics of globalization. Cambridge University Press.

Blommaert, J., \& Rampton, B. (2012). Language and superdiversity. MMG Working Paper, (12-09). http:/ hdl.handle.net/11858/00-001M-0000-000E-7CFE-9

Bourdieu, P. (1991). Language and symbolic power. Harvard University Press.

Bourdieu, P., \& Passeron, J. C. (1990). Reproduction in education, society and culture. SAGE.

Bourdieu, P., \& Wacquant, L. J. (1992). An invitation to reflexive sociology. University of Chicago Press.

Bresler, L. (2021). The form, rhythm, and orchestration of an academic career: Cultivating and navigating inner compasses within institutional terrains [Online First]. Research Studies in Music Education. https://doi.org/10.1177/1321103X211036327

Brittain, E. (2020). Reinforcement of White Native-Speakerism: An Analysis of English Language Teacher Training Materials. GATESOL in Action Journal, 30(1), 16-31. https://doi. org/10.52242/giaj.v30i1.105

Brown, L. B. (1992). Adorno's critique of popular culture: The case of jazz music. Journal of Aesthetic Education, 26(1), 17-31.

Cañas, C., Ocampo, A. P., Rodríguez, A. K., López-Ladino, M., \& Mora, R. A. (2018). Toward a participatory view of early literacies in second language contexts: a reflection on research from Colombia. In G. Onchwari \& J. Keengwe (Eds.), Handbook of research on pedagogies and cultural considerations for young English language learners (pp. 300-324). IGI Global. https://doi. org/10.4018/978-1-5225-3955-1.ch015

Castrillón-Ángel, E. F., \& Mora, R. A. (2021). Rethinking CDL practices in second-language teacher education through podcasting. In J. Ávila (Ed.), Critical digital literacies: Boundary-crossing practices (pp. 205-230). Brill.

Castro-Garcés, A. Y. (2021). Awakening sociocultural realities in pre-service teachers through a pedagogy of multiliteracies. GIST-Education and Learning Research Journal, (22), 173-197. https://doi.org/10.26817/16925777.844

Chiquito, T., Restrepo, A., \& Mora, R. A. (2019). Now, New, Next: A Look at YAL from the South through the eyes and words of our younger teachers. The ALAN Review, 46(3), 104-109. http://www.alan-ya.org/wp-content/uploads/2014/11/m104-109-ALAN-Summer19.pdf

Cruz Arcila, F. (2018). The Wisdom of teachers' personal theories: Creative ELT practices from Colombian rural schools. Profile: Issues in Teachers' Professional Development, 20(2), 65-78. https:/ / doi.org/10.15446/profile.v20n2.67142

d., --e., \& Zapata-Pescador, D. (2021, October 14-16). Queer critical literacy: Exploring structures of privilege in education [Paper Presentation]. 56th ASOCOPI Online Annual Conference.

Denzin, N. K. (2013). Interpretive autoethnography. SAGE. 
Forber-Pratt, A. J. (2015). “You're going to do what?” Challenges of autoethnography in the academy. Qualitative Inquiry, 21(9), 821-835. https://doi.org/10.1177/1077800415574908

Freire, P. (2000). Pedagogy of the heart. Continuum.

Freire, P., \& Macedo, D. (1987). Literacy: Reading the word and the world. Routledge.

Giraldo, M., \& Castaño, S. (2014). Superdiversity. LSLP Micro-Papers, 2. https://www.literaciesinl2project.org/uploads/3/8/9/7/38976989/1slp-micro-paper-2-superdiversity.pdf

González, A. (2010). English and English teaching in Colombia: Tensions and possibilities in the expanding circle. In A. Kirkpatrick (Ed.), The Routledge handbook of world Englishes (pp. 332352). Routledge.

Guerrero Nieto, C. H., \& Quintero Polo, Á. H. (2009). English as a neutral language in the Colombian national standards: A constituent of dominance in English language education. Profile: Issues in Teachers' Professional Development, 11(2), 135-150. https://revistas.unal.edu.co/index. $\mathrm{php} / \mathrm{profile} /$ article/view/11447

Guerrero, C. H. (2009). Language policies in Colombia: The inherited disdain for our native languages. $\mathrm{HOW}, 16,11-24$.

hooks, b. (2000). Feminism is for everybody: Passionate politics. Pluto Press.

Jones, S. (2007). Antonio Gramsci. Routledge.

Kubota, R. (2021). Critical antiracist pedagogy in ELT. ELT Journal, 75(3), 237-246.

Ladson-Billings, G. (1998). Just what is critical race theory and what's it doing in a nice field like education? International Journal of Qualitative Studies in Education, 11(7), 7-24. https://doi. org/10.1080/095183998236863

Ladson-Billings, G. (2006). From the achievement gap to the education debt: Understanding achievement in US schools. Educational Researcher, 35(7), 3-12. https://doi. org/10.3102/0013189X035007003

Love, B. L. (2019). We want to do more than survive: Abolitionist teaching and the pursuit of educational freedom. Beacon Press.

Luke, A. (2017). No grand narrative in sight: On double consciousness and critical literacy. Literacy research: Theory, method, and practice, 66(1), 157-182. https://doi.org/10.1177/2381336917718805

Mora, R. A. (2011, August). ESL/EFL: Still a viable binary? $2^{\text {nd }}$ Colloquia on Research and Innovation in Foreign Language Education 2011, Bogotá D.C., Colombia

Mora, R. A. (2011, September). Understanding what literacy is and where it comes from: Lessons and implications from a study of teachers and teacher educators. Keynote Presentation at the $14^{\text {th }}$ National ELT Conference, Bogotá D.C., Colombia (ED547649). ERIC. https://files.eric.ed.gov/fulltext/ ED547649.pdf

Mora, R. A. (2012, October). Retbinking the second/foreign language dichotomy: Can we still talk about foreign languages in today's language ecologies? [Plenary Address] 47 ${ }^{\text {th }}$ ASOCOPI Annual Conference, Tuluá (Valle), Colombia. 
Mora, R. A. (1999). Using project work to develop and practice writing skills. HOW, 6, 53-58. https://www.howjournalcolombia.org/index.php/how/article/view/248/296

Mora, R. A. (2009). It's not how literate we are, but how we are literate. ASOCOPI Newsletter, August, 2-5. http://asocopi.org/files/Newsletter_August_2009.pdf

Mora, R. A. (2012). Bourdieu y la formación de docentes: Reflexividad sobre los retos y horizontes en el campo de la educación. Revista Pensamiento Universitario, 23, 55-62.

Mora, R. A. (2013a, September). Have we told our children why they should learn another language? A critical discussion on the new roles and questions for language learning in Colombia. Seminario Miradas Contemporáneas en Educación, Universidad Distrital "Francisco José de Caldas", Bogotá. D.C. https://www.youtube.com/watch?v=Yje0AnkuTXo

Mora, R. A. (2013b). The notion of second languages: Responding to today's linguistic ecologies. The Journal for ESL Teachers and Learners, Vol. II, 53-61. http://www.confluenceindia.co.in/ wp-content/uploads/2013/08/8-Raul-Mora.pdf

Mora, R. A. (2014a). Conscientização. Key Concepts in Intercultural Dialogue, 42. https://centerforinterculturaldialogue.files.wordpress.com/2014/11/key-concepts-conscientizaccca7acc83o. pdf

Mora, R. A. (2014b). Counter-narrative. Key Concepts in Intercultural Dialogue, 36. http://centerforinterculturaldialogue.files.wordpress.com/2014/05/key-concept-counter-narrative.pdf

Mora, R. A. (2014c). Critical literacy as policy and advocacy: Lessons from Colombia. Journal of Adolescent \& Adult Literacy, 58(1). 16-18. https://doi.org/10.1002/jaal.329

Mora, R. A. (2014d). La importancia de una postura crítica ante el < bilingüismo> para la formación de jóvenes líderes. In L. Reales Jiménez (Ed.), De los derechos humanos al emprendimiento y la prosperidad en Colombia: Memorias de la Cátedra ASOUS A 2012-2014 (pp. 188-195). Corporación Acción Ciudadana Colombia - AC Colombia.

Mora, R. A. (2014e). Reflexivity. Key Concepts in Intercultural Dialogue, 21. https://centerforinterculturaldialogue.files.wordpress.com/2014/06/key-concept-reflexivity.pdf

Mora, R. A. (2015). City literacies in second languages: New questions for policy and advocacy. Journal of Adolescent \& Adult Literacy, 59(1), 21-24. https://doi.org/10.1002/jaal.440

Mora, R. A. (2016a). Glocalized advocacy. LSLP Micro-Papers, 37. https://www.literaciesinl2project.org/uploads/3/8/9/7/38976989/1slp-micro-paper-37-glocalized-advocacy.pdf

Mora, R. A. (2016b). Translating literacy as global policy and advocacy. Journal of Adolescent \& Adult Literacy, 59(6), 647-651. https://doi.org/:10.1002/jaal.515

Mora, R. A. (2017a). Lost in translation: A reflection on the absence of second-language teachers in media. In M. Dalton \& L. R. Linder (Eds.), Screen lessons: What I have learned from teachers on television and in the movies (pp. 159-164). Peter Lang.

Mora, R. A. (2017b, September). From EFL to ECL to CE: Seeking more equitable language learning and teaching practices for our ELT communities and teacher education programs [Plenary Address]. Forum on the Future of the ELT Profession in Colombia 2017, Bogotá D.C., Colombia. 
Mora, R. A. (2019, May 31). What will it take for us to have bilingualism in Colombia? A blueprint for the incoming decade. Licenciatura en Bilingüismo, Universidad Tecnológica de Pereira, Colombia. https://www.youtube.com/watch?v=Li0S7anRs'TU\&t=1365s

Mora, R. A., \& Golovátina-Mora, P. (2011, August). Bilingualism - A bridge to cosmopolitanism? Keynote Presentation at the ELT Conference 2011, Medellín, Colombia (ED547646). ERIC. https://files.eric.ed.gov/fulltext/ED547646.pdf

Mora, R. A., \& Golovátina-Mora, P. (2017a). A new model for reflexivity and advocacy for master'slevel EIL in-service programs in Colombia: The notion of "learning and teaching processes in second languages". In A. Matsuda (Ed.), Preparing teachers to teach English as an International Language (pp. 35-50). Multilingual Matters. https://doi.org/10.21832/9781783097036-005

Mora, R. A., \& Golovátina-Mora, P. (2017b, May 17-20). Research and marriage: A contemplative duoethnography of growth [Paper presentation]. Thirteenth International Congress of Qualitative Inquiry, University of Illinois at Urbana-Champaign.

Mora, R. A. \& Lopera Gómez, M.C. (2001). Games in the classroom: more than just having fun. HOW, A Colombian Journal for English Teachers, 8(1), 75-82. https://www.howjournalcolombia. org/index.php/how/article/view/220/269

Mora, R. A., Cañas, C., Gutiérrez-Arismendy, G., Ramírez, N. A., Gaviria, C. A., \& Golovátina-Mora, P. (2021). Critical literacies in Colombia: Social transformation and disruption ingrained in our local realities. In J. Z. Pandya, R. A. Mora, J. H. Alford, N. A. Golden, \& R. S. de Roock (Eds.), The handbook of critical literacies (pp. 151-158). Routledge.

Mora, R. A., Cañas, C., Rosas Chávez, P., Rocha, C. H., \& Maciel, R. F. (2020). In Dialogue: Latin America. Research in the Teaching of English, 54(4), 439-451.

Mora, R. A., Chiquito, T., \& Zapata, J. D. (2019). Bilingual education policies in Colombia: Seeking relevant and sustainable frameworks for meaningful minority inclusion. In B. G. G. Johannessen (Ed.), Bilingual education: Politics, policies, and practices in a globalized society (pp. 55-77). Springer. https://doi.org/10.1007/978-3-030-05496-0_4

Mora, R. A., Pandya, J. Z., Alford, J. H., Golden, N. A., \& de Roock, R. S. (2021). Conclusion: Critical literacy and the new world ahead of us. In J. Z. Pandya, R. A. Mora, J. H. Alford, N. A. Golden, \& R. S. de Roock (Eds.), The handbook of critical literacies (pp. 465-471). Routledge.

Mora, R. A., Pulgarín, C., Ramírez, N., \& Mejía-Vélez, M. C. (2018). English literacies in Medellin: The city as literacy. In S. Nichols \& S. Dobson (Eds.), Learning cities: Multimodal explorations and placed pedagogies (pp. 37-60). Springer. https://doi.org/10.1007/978-981-10-8100-2_4

Mora, R. A., Tobón-Gallego, A. E., Mejía-Vélez, M. C., \& Agudelo, E. (2022). Bridging multimodality and criticality to language education with a twist from the Global South: Multimodal Critical Consciousness as Multimodal Conscientização. In S. R. Barros \& L. C. de Oliveira (Eds.), Paulo Freire and Multilingual Education: Theoretical Approaches, Methodologies and Empirical Analyses in Language and Literacy. Routledge. [In press]

Ortega, Y. (2019). “Teacher, ¿Puedo Hablar en Español?” A reflection on plurilingualism and translanguaging practices in EFL. Profile: Issues in Teachers' Professional Development, 21(2), 155170. https://doi.org/10.15446/profile.v21n2.74091 
Parker, L. (1998). 'Race is race ain't': an exploration of the utility of critical race theory in qualitative research in education. International Journal of Qualitative Studies in Education, 11(1), 43-55. https://doi.org/10.1080/095183998236881

Ramírez, N. A. (2020, November 26-27). Critical literacy as a tool for social emancipation in Colombian ELT [Paper presentation]. 3rd International Symposium on Research in Foreign Language Teaching [Online], Universidad Surcolombiana. https://sites.google.com/usco.edu. $\mathrm{co} / 3$ rd-internationalsymposium/program

Ramírez, N. A. (2021). A meta-analysis of critical literacy qualitative studies on preservice teacher education in Colombia [Unpublished Master's Thesis]. Universidad Pontificia Bolivariana.

Rincón, J., \& Clavijo-Olarte, A. (2016). Fostering EFL learners' literacies through local inquiry in a multimodal experience. Colombian Applied Linguistics Journal, 18(2), 67-82. https://doi. org/10.14483/calj.v18n2.10610

Rosa, J., \& Flores, N. (2017). Unsettling race and language: Toward a raciolinguistic perspective. Language in society, 46(5), 621-647.

Sierra Piedrahita, A. M. (2016). Contributions of a social justice language teacher education perspective to professional development programs in Colombia. Profile Issues in Teachers Professional Development, 18(1), 203-217. https://doi.org/10.15446/profile.v18n1.47807

Solórzano, D. G., \& Yosso, T. J. (2001). Critical race and LatCrit theory and method: Counter-storytelling. Qualitative Studies in Education, 14(4), 471-495. https://doi. org/10.1080/09518390110063365

Trigos-Carrillo, L. (2019), Community cultural wealth and literacy capital in Latin American communities. English Teaching: Practice \& Critique, 19(1), 3-19. https://doi.org/10.1108/ETPC-052019-0071

Walters, M. (2005). Feminism: A very short introduction. Oxford University Press.

Willis, A. I. (2008). Critical race theory. In B. V. Street \& N. Hornberger (Eds.), Encyclopedia or language and education, $2^{\text {nd }}$ Edition, Volume 2: Literacy (pp. 15-28). Springer.

Willis, A. I. (2009). EduPolitical research: Reading between the lines. Educational Researcher, 38(7), 528-536. https://doi.org/10.3102/0013189X09347584

Willis, A. I. (2015). Literacy and race: Access, equity, and freedom. Literacy Research: Theory, Method, and Practice, 64(1), 23-55. https://doi.org/10.1177/2381336915617617

Willis, A. I. (2019). Race, response to intervention, and reading research. Journal of Literacy Research, 51(4), 394-419. https://doi.org/10.1177/1086296X19877463

Witkin, R. W. (2003). Adorno on popular culture. Routledge. 